\title{
Enhanced Interferon-a2b Production in Periplasmic Space of Escherichia coli through Medium Optimization using Response Surface Method
}

\author{
Joo Shun Tan ${ }^{1}$, Ramakrishnan Nagasundara Ramanan ${ }^{1}$, Siti Nor Ani Azaman ${ }^{1}$, Tau Chuan Ling ${ }^{2}$, \\ Mustapha Shuhaimi ${ }^{3}$ and Arbakariya B. Ariff*,1,4
}

\author{
${ }^{I}$ Unit of Immunotherapeutic \& Vaccine, Laboratory of Molecular Biomedicine, Institute of Bioscience, Universiti Putra \\ Malaysia, 43400 Serdang, Selangor, Malaysia \\ ${ }^{2}$ Department of Process and Food Engineering, Faculty of Engineering, Universiti Putra Malaysia, 43400 Serdang, \\ Selangor, Malaysia \\ ${ }^{3}$ Department of Microbiology, Faculty of Biotechnology and Biomolecular Sciences, Universiti Putra Malaysia, 43400 \\ Serdang, Selangor, Malaysia \\ ${ }^{4}$ Department of Bioprocess Technology, Faculty of Biotechnology and Biomolecular Sciences, Universiti Putra \\ Malaysia, 43400 Serdang, Selangor, Malaysia
}

\begin{abstract}
The influence of different carbon and nitrogen sources on growth of recombinant Escherichia coli and human interferon- $\alpha 2 \mathrm{~b}$ (IFN- $\alpha 2 \mathrm{~b}$ ) production in periplasmic space was studied in shake flask culture. A statistical method based on Plackett-Burman design was used to screen the main medium components that greatly influenced the performance of the fermentation process. The optimization of medium was performed using response surface methodology (RSM) where three critical factors (glucose, yeast extract and peptone) were optimized using central composite design. The highest yield of periplasmic recombinant human interferon- $\alpha 2 \mathrm{~b}$ (PrIFN- $\alpha 2 \mathrm{~b})(335.8 \mu \mathrm{g} / \mathrm{L})$ was predicted to be obtained in optimized medium containing $5.47 \mathrm{~g} / \mathrm{L}$ glucose, $55.24 \mathrm{~g} / \mathrm{L}$ yeast extract and $42.27 \mathrm{~g} / \mathrm{L}$ peptone.. The production of IFN- $\alpha 2 \mathrm{~b}$ in periplasmic space in optimized medium was about 2.5, 11.7 and 124.4 times higher than Terrific broth (TB), Luria-Bertani (LB), and minimal medium (M9), respectively.
\end{abstract}

Keywords: Escherichia coli, Human interferon- $\alpha 2 b$, Plackett-Burman, Optimization, Response surface methodology.

\section{INTRODUCTION}

Escherichia coli is well characterized in terms of molecular genetics, physiology and expression systems, which makes it easier to be manipulated and used as host cells system [1]. The production of proteins through E. coli has more advantages than other ways of production. Strategies for promoting the expression of heterologous protein in periplasmic spaces of $E$. coli have been intensively studied [2]. The secretion of targeted recombinant proteins via translocation across the cytoplamic membrane to periplasmic space has been a potential strategy for proteins production especially for pharmaceutical products [3]. The expression of periplasmic protein would overcome the problems of protein misfolding, insoluble aggregation forming inclusion bodies, and incorrect $\mathrm{N}$-terminal of mature protein that normally occurred during cytoplasmic synthesis [4]. In addition, the periplasmic space also provided a more oxidative and less protease activity environment compared to cytoplasm [5].

Interferons (IFNs) are glycoproteins involved in antiviral, antiproliferative, and immunoregulatory process [6]. There are three major types of human IFN: alpha (leucocytes), beta

*Address correspondence to this author at the Department of Bioprocess Technology, Faculty of Biotechnology and Biomolecular Sciences, Universiti Putra Malaysia, 43400 Serdang, Selangor, Malaysia; Tel: +603 89467591; Fax: +603 89467510; E-mail: arbarif@biotech.upm.edu.my (fibroblasts) and gamma (immune). To variety of different threats, the diversity of IFN provides different immune response. Alpha IFN was found to be effective against chronic hepatitis B and C [7] as well as autoimmune diseases [8]. The IFN- $\alpha 2 b$ has been previously expressed in $E$. coli under T7 promoter [9, 10] and lipoprotein-lactose promoter [11]. Recently, production of periplasmic recombinant human interferon- $\alpha 2 \mathrm{~b}$ (PrIFN- $\alpha 2 \mathrm{~b}$ ) in Pichia pastoris using different secretion signals has been reported [12]. Periplasmic proteins of $E$. coli were highly resistant to the formation of aggregates which subsequently reduces downstream processing cost [13].

Commercial media such as Terrific broth (TB), LuriaBertani (LB) and minimal media (M9) were normally used for the expression of IFN- $\alpha 2 b$. Similar specific product yield of IFN- $\alpha 2 b$ was obtained in LB and M9 media, but the yield was significantly higher in TB medium [14]. In all cases, the IFN- $\alpha 2 b$ was produced in the form of inclusion bodies. Report on the optimization of media for enhancement of IFN$\alpha 2 \mathrm{~b}$ production in periplasmic space of $E$. coli is not available in the literature.

The main objective of the present study was to optimize the overall productivity of PrIFN- $\alpha 2 b$ using statistical approach. A screening design of Plackett-Burman was used to select the significant variables affecting the PrIFN- $\alpha 2 b$ production. The significant variables selected from the screen- 
ing design were then used in the optimization of PrIFN- $\alpha 2 b$ expression using response surface method.

\section{MATERIALS AND METHODS}

\section{The Recombinant Strain}

Recombinant bacterium, E. coli strain Rosetta-gami ${ }^{\mathrm{TM}}$ 2(DE3), capable of producing IFN- $\alpha 2 b$ was used in this study. Rosetta-gami 2(DE3) host strain combines the features of Origami and Rosetta, allowing for enhanced disulfide bond formation and enhanced expression of eukaryotic proteins as it contain codons rarely used in E. coli. pET26bIFN was prepared by inserting the coding sequence of IFN$\alpha 2 b$ in pET26b (Cat No. 69862-3, Novagen) using PCR based subcloning strategy. pET26b contains T7lac promoter and pelB signal sequence to aid the transfer of IFN- $\alpha 2 b$ to periplasmic area. The stock culture of Rosetta-gami 2(DE3) was grown on $\mathrm{LB}$ medium at $37^{\circ} \mathrm{C}$ until the optical density $\left(\mathrm{OD}_{600}\right)$ of the culture reached the values ranged from 0.4 to 0.6 . For cell preservation, glycerol $(10 \%)$ was added to the culture in the $1.5 \mathrm{~mL}$ microcentrifuge tube and stored at $-80^{\circ} \mathrm{C}$.

\section{Inoculum Preparation}

The inoculum was prepared by using $2 \%$ of stock culture into $50 \mathrm{~mL}$ TB medium supplemented with $30 \mathrm{mg} / \mathrm{L} \mathrm{ka-}$ namycin and $34 \mathrm{mg} / \mathrm{L}$ chloramphenicol. The culture was grown at $37^{\circ} \mathrm{C}$ with a constant shaking at $250 \mathrm{rpm}$ for $16 \mathrm{~h}$.

\section{Fermentation}

To start the fermentation, $8 \%(\mathrm{v} / \mathrm{v})$ of inoculum was inoculated into $250 \mathrm{~mL}$ baffled shake flasks containing $50 \mathrm{~mL}$ of the sterilized medium. The flasks were incubated at $37^{\circ} \mathrm{C}$ in an incubator shaker, agitated at $250 \mathrm{rpm}$. The cultures were induced with $1 \mathrm{mM}$ IPTG after $4 \mathrm{~h}$ of cultivation and the temperature was switched to $30^{\circ} \mathrm{C}$. Samples were withdrawn at time intervals after the induction for analysis.

\section{Medium Composition and Experimental Design}

Three types of basal medium (TB, LB and M9) were tested for the growth of $E$. coli and production of PrIFN- $\alpha 2 \mathrm{~b}$. TB consists of tryptone $(12 \mathrm{~g} / \mathrm{L})$, yeast extract $(24 \mathrm{~g} / \mathrm{L})$, $\mathrm{KH}_{2} \mathrm{PO}_{4}(2.31 \mathrm{~g} / \mathrm{L}), \mathrm{K}_{2} \mathrm{HPO}_{4}(12.54 \mathrm{~g} / \mathrm{L})$ and glycerol $(4.0$ $\mathrm{g} / \mathrm{L})$. LB consists of glucose $(0.4 \mathrm{~g} / \mathrm{L})$, tryptone $(10.0 \mathrm{~g} / \mathrm{L})$, yeast extract $(5.0 \mathrm{~g} / \mathrm{L})$ and $\mathrm{NaCl}(10.0 \mathrm{~g} / \mathrm{L})$. On the other hand, the M9 consists of glucose $(20 \mathrm{~g} / \mathrm{L}), \mathrm{Na}_{2} \mathrm{HPO}_{4}(12.5$ $\mathrm{g} / \mathrm{L}), \mathrm{KH}_{2} \mathrm{PO}_{4}(3 \mathrm{~g} / \mathrm{L}) \mathrm{NaCl}(0.5 \mathrm{~g} / \mathrm{L})$, ammonium sulphate $(1.0 \mathrm{~g} / \mathrm{L}) ; 1 \mathrm{M}$ magnesium sulphate $(2 \mathrm{~g} / \mathrm{L})$ and $\mathrm{CaCl}_{2}(0.1$ $\mathrm{g} / \mathrm{L})$.

Optimization study was performed based on the modified composition of TB with some additional factors. The composition of the medium was varied according to the needs of each experiment. In the preliminary experiments, evaluation of various essential variables was carried out. Effects of carbon and nitrogen sources were investigated with multifactor experimental design (change-one-factor-at-a-time) approach. It was applied by the variation of a single factor while other factors were kept constant. Plackett-Burman experimental design was used for initial screening of the important medium components with respect to their main effects. Seven numerical variables (glucose, glycerol, yeast extract, peptone, magnesium sulphate, $\mathrm{NaCl}$ and initial $\mathrm{pH}$ ) were selected and conducted in twelve experimental runs for the screening process in one block (Table 4). The remainders were used as dummy factors for estimating errors.

A full factorial central composite design (CCD) was applied in the second stage to further optimize the significant variables selected by Plackett-Burman. In the CCD, the three factors (glucose, yeast extract and peptone) selected were tested in twenty experiments. The range of carbon and nitrogen sources concentrations used in this study was 3 to $10 \mathrm{~g} / \mathrm{L}$ and 20 to $60 \mathrm{~g} / \mathrm{L}$, respectively. They were incorporated in the basal media and the effect of these nutrients on PrIFN- $\alpha 2 b$ production by $E$. coli was determined. The medium constituents that yield the maximum production of PrIFN- $\alpha 2 b$ were identified.

\section{Analytical Methods}

During the fermentations, $10 \mathrm{~mL}$ of culture samples were withdrawn at time intervals for analysis. Cell concentration was quantified by optical density (OD) and dry cell weight (DCW). The OD of the culture sample was measured by UV/VIS spectrophotometer (Lambda 25, PerkinElmer) at $600 \mathrm{~nm}$. For dry cell weight determination, $5 \mathrm{~mL}$ of sample was vacuum filtered and the supernatant was discarded. The cell pellet on the $0.2 \mu \mathrm{m}$ cellulose nitrate filter paper was dried overnight in an oven at $90^{\circ} \mathrm{C}$ until a constant weight was obtained. The relationship between dry cell weight and $\mathrm{OD}_{600}$ was observed as $0.278 \mathrm{~g} \mathrm{DCW} / \mathrm{L} / \mathrm{OD}_{600}$.

Another $5 \mathrm{~mL}$ of the culture sample was centrifuged at $8,000 \mathrm{x} \mathrm{g}$ for $10 \mathrm{~min}$ at $4^{\circ} \mathrm{C}$. The supernatant was collected for glucose and glycerol content determination while the cell pellet was used for the extraction and determination of PrIFN- $\alpha 2 \mathrm{~b}$. The pellet was re-suspended in $5 \mathrm{~mL}$ solution containing $20 \%$ sucrose, $33 \mathrm{mM}$ Tris, and $5 \mathrm{mM}$ EDTA at $\mathrm{pH}$ 8. The mixture was incubated at $30^{\circ} \mathrm{C}$ with shaking for 5 min to enhance osmotic shock. It was then centrifuged at $8,000 \times \mathrm{g}$ for $10 \mathrm{~min}$ at $4^{\circ} \mathrm{C}$ and the supernatant was discarded. The shrunk cells were rapidly re-suspended in icecold distilled water $(5 \mathrm{~mL})$ and incubated with shaking for $15 \mathrm{~min}$. The mixture was then centrifuged at $8,000 \mathrm{xg}$ for 10 min at $4{ }^{\circ} \mathrm{C}$ and the supernatant was collected for the determination of PrIFN- $\alpha 2 b$.

The quantity of PrIFN- $\alpha 2 b$ was determined using Fully Automated Surface Plasma Resonance Detection System (BIAcore 3000, GE HealthCare) according to the method described by Ramanan et al. [15].

The acetic acid concentration of the sample was analyzed using reverse-phase high performance liquid chromatography (RP-HPLC). RP-HPLC analysis was performed on a shodex SH-1011 column $(7 \mu \mathrm{m}, 8 \mathrm{~mm} \times 300 \mathrm{~mm})$ which connected with shodex SH-G guard column $(7 \mu \mathrm{m}, 6 \times 50$ $\mathrm{mm})$. Solvent was $5 \mathrm{mM}$ sulphuric acid and the flow rate was $0.8 \mathrm{~mL} / \mathrm{min}$. Detection was performed at $210 \mathrm{~nm}$ with automatic data processing using Empower software for data acquisition and analysis.

Glycerol was determined enzymatically using free glycerol reagent (Cat No. F6428, Sigma). All analyses were conducted in triplicates. 


\section{RESULTS AND DISCUSSION}

\section{Selection of Basal Medium}

The effect of using three different types of basal medium (TB, LB and M9) on growth of $E$. coli and production of PrIFN- $\alpha 2 \mathrm{~b}$ is shown in Table 1. The highest growth of $E$. coli $(9.32 \mathrm{~g} / \mathrm{L})$ and production of PrIFN- $\alpha 2 \mathrm{~b}(134.7 \mu \mathrm{g} / \mathrm{L})$ was obtained in TB. A great reduction in the production of PrIFN- $\alpha 2 b$ was observed in fermentation using LB though growth was slightly inhibited. Both growth and PrIFN- $\alpha 2 b$ production was greatly inhibited in fermentation using a M9 medium.

The final PrIFN- $\alpha 2 b$ concentration obtained in fermentation using TB was about 4.7-fold and 50-fold higher than those obtained in LB $(28.6 \mu \mathrm{g} / \mathrm{L})$ and $\mathrm{M} 9(2.7 \mu \mathrm{g} / \mathrm{L})$, respectively. On the other hand, the specific yield of PrIFN- $\alpha 2 b$ production by $E$. coli in fermentation using TB was about 15 -fold and 3.5-fold higher than those obtained in fermentation using M9 and LB, respectively. This result suggests that the production of PrIFN- $\alpha 2 b$ was not linearly related to growth of E. coli. In term of volumetric productivity, the value obtained for fermentation using TB $(16.8 \mu \mathrm{g} / \mathrm{L} / \mathrm{h})$ was also substantially higher than those obtained in LB (3.6 $\mu \mathrm{g} / \mathrm{L} / \mathrm{h})$ and $\mathrm{M} 9(0.3 \mu \mathrm{g} / \mathrm{L} / \mathrm{h})$.

Increase in growth of $E$. coli and PrIFN- $\alpha 2 \mathrm{~b}$ production in TB may be related to high content of total nitrogen (156 $\mathrm{mM})$ contributed by yeast extract $(24 \mathrm{~g} / \mathrm{L})$ and tryptone (12 $\mathrm{g} / \mathrm{L}$ ). Total nitrogen in LB was only $70 \mathrm{mM}$, contributed from $12 \mathrm{~g} / \mathrm{L}$ yeast extract and $10 \mathrm{~g} / \mathrm{L}$ peptone. M9 (37.3 $\mathrm{mM}$ ) only contained basic nutrients for the growth of E. coli, thus growth and PrIFN- $\alpha 2 b$ was greatly reduced. Since the use of TB enhanced growth of E. coli and PrIFN- $\alpha 2 \mathrm{~b}$ pro- duction, this medium was selected for subsequent use in the statistical optimization for further improvement of the fermentation process.

\section{Effect of Carbon Source on Growth of $E$. coli and PrIFN- a2b Production}

Table 2 shows that growth of E. coli was the highest in fermentation using glucose $(0.27 \mathrm{~g} / \mathrm{L})$, followed by glycerol $(0.16 \mathrm{~g} / \mathrm{L})$ and sucrose $(0.07 \mathrm{~g} / \mathrm{L})$. Similarly, production of PrIFN- $\alpha 2 b$ was also the highest in glucose $(14.9 \mu \mathrm{g} / \mathrm{L})$, followed by glycerol $(5.2 \mu \mathrm{g} / \mathrm{L})$ and sucrose $(2.3 \mu \mathrm{g} / \mathrm{L})$. This result suggests that production of PrIFN- $\alpha 2 b$ was very much related to cell concentration. However, the relationship was not linear. For example, PrIFN- $\alpha 2 b$ concentration in fermentation using glucose was about $65 \%$ higher than that obtained in glycerol, but the specific yield was only $41 \%$ higher. This means that the expression of PrIFN- $\alpha 2 \mathrm{~b}$ by cells grown in glucose was lower compared to cells grown in glycerol.

Acetic acid accumulation in glucose $(0.169 \mathrm{~g} / \mathrm{L})$ was substantially higher than in glycerol $(0.098 \mathrm{~g} / \mathrm{L})$ and sucrose $(0.1 \mathrm{~g} / \mathrm{L})$ medium. High concentration of acetic acid which co-produced by $E$. coli in glucose medium was assumed to repress the growth of $E$. coli. Glycerol can be used to increase the solubility and activity of recombinant proteins [16], and the use of low concentration of glucose may reduce inhibition to growth of $E$. coli due to acetate accumulation. Thus, the use of glucose and glycerol as a mixed carbon source may enhance the production of PrIFN- $\alpha 2 b$ by $E$. coli and this aspect was considered in the screening using Plackett-Burman.

Table 1. Effect of Three Types of Basal Medium and Optimized Medium on Growth of E. coli and Production of PrIFN-a2b

\begin{tabular}{|c|c|c|c|c|c|c|c|c|}
\hline Media & $\begin{array}{l}\text { Final cell Con- } \\
\text { centration } \\
(\mathrm{g} / \mathrm{L})\end{array}$ & $\begin{array}{c}\text { Total } \\
\text { C } \\
(\mathrm{mM})\end{array}$ & $\begin{array}{c}\text { Total N } \\
(\mathrm{mM})\end{array}$ & $\begin{array}{c}\text { C/N } \\
\text { Ratio }\end{array}$ & $\begin{array}{c}\text { Final PrIFN-a2b } \\
\text { Concentration } \\
(\mu \mathrm{g} / \mathrm{L})\end{array}$ & $\begin{array}{c}\text { Specific } \\
\text { Yield } \\
(\mu \mathrm{g} / \mathrm{g} \text { of Cell })\end{array}$ & $\begin{array}{c}\text { Fermentation } \\
\text { Time (h) }\end{array}$ & $\begin{array}{c}\text { Volumetric } \\
\text { Productivity }(\mu \mathrm{g} / \mathrm{L} / \mathrm{h})\end{array}$ \\
\hline Terrific broth & $9.32(0.515)$ & 13 & 156 & 0.08 & $134.7(0.653)$ & 14.5 & 8 & 16.8 \\
\hline Minimal medium & $2.84(0.159)$ & 2.67 & 37.3 & 0.07 & $2.7(0.223)$ & 1.0 & 8 & 0.3 \\
\hline Luria-Bertani & $6.86(0.354)$ & 13 & 70 & 0.19 & $28.6(1.112)$ & 4.2 & 8 & 3.6 \\
\hline $\begin{array}{l}\text { Optimized } \\
\text { medium }\end{array}$ & $9.89(0.635)$ & 508 & 470 & 1.08 & $329.2(13.937)$ & 33.3 & 8 & 41.2 \\
\hline
\end{tabular}

The results of final cell concentration and final PrIFN- $\alpha 2 b$ are the average of duplicate experiments. The value in bracket is the standard deviation. Specific yield and volumetric productivity are calculated with the average values. Fermentation time is the time taken from inoculation to reach a maximum concentration of PrIFN- $\alpha 2 \mathrm{~b}$.

Table 2. Effect of Three Different Types of Carbon Sources on Growth of E. coli and Production of PrIFN- $\alpha 2 b$.

\begin{tabular}{|c|c|c|c|c|c|c|}
\hline $\begin{array}{c}\text { Carbon } \\
\text { Source }\end{array}$ & $\begin{array}{c}\text { Final Cell } \\
\text { Concentration (g/L) }\end{array}$ & $\begin{array}{c}\text { Final PrIFN- } \mathbf{\alpha 2 b} \\
\text { Concentration }(\boldsymbol{\mu g} / \mathbf{L})\end{array}$ & $\begin{array}{c}\text { Specific Yield } \\
(\boldsymbol{\mu g} / \mathbf{g} \text { of Cell) }\end{array}$ & $\begin{array}{c}\text { Fermentation } \\
\text { Time (h) }\end{array}$ & $\begin{array}{c}\text { Volumetric } \\
\text { Productivity }(\boldsymbol{\mu g} / \mathbf{L} / \mathbf{h})\end{array}$ & $\begin{array}{c}\text { Final Acetic Acid } \\
\text { Concentration }(\mathbf{g} / \mathbf{L})\end{array}$ \\
\hline \hline Glucose & $0.27(0.056)$ & $14.9(3.578)$ & 55.2 & 8 & 1.9 & 0.169 \\
\hline Glycerol & $0.16(0.054)$ & $5.2(2.539)$ & 32.5 & 8 & 0.7 & 0.098 \\
\hline Sucrose & $0.07(0.044)$ & $2.3(0.239)$ & 32.9 & 8 & 0.3 & 0.100 \\
\hline
\end{tabular}

The quantity of each carbon source used was $10 \mathrm{~g} / \mathrm{L}$. Ammonium sulfate $(10 \mathrm{~g} / \mathrm{L})$ was used as a nitrogen source for all the experiments. The results of final cell concentration and final PrIFN- $\alpha 2 \mathrm{~b}$ are the average of duplicate experiments. The value in bracket is the standard deviation. Specific yield and volumetric productivity are calculated with the average values. Fermentation time is the time taken from inoculation to reach a maximum concentration of PrIFN- $\alpha 2 b$. 
Effect of Nitrogen Source on Growth of $E$. coli and Production of PrIFN- $\alpha 2 b$

The effect of different nitrogen sources on growth of $E$. coli and production of PrIFN- $\alpha 2 \mathrm{~b}$ is shown in Table 3. The highest cell concentration $(0.64 \mathrm{~g} / \mathrm{L})$ was obtained when yeast extract was used as the sole nitrogen source followed by peptone $(0.48 \mathrm{~g} / \mathrm{L})$, casamino acid $(0.39 \mathrm{~g} / \mathrm{L})$ and ammonium sulphate $(0.32 \mathrm{~g} / \mathrm{L})$. Similar trend was also observed in the production of PrIFN- $\alpha 2 b$ where the PrIFN- $\alpha 2 b$ was the highest in yeast extract $(20.8 \mu \mathrm{g} / \mathrm{L})$, followed by peptone $(3.8 \mu \mathrm{g} / \mathrm{L})$, casamino acid $(0.8 \mu \mathrm{g} / \mathrm{L})$ and ammonium sulphate $(0.1 \mu \mathrm{g} / \mathrm{L})$.

Yeast extract is more effective for improving cell yields and overall recombinant protein expression compared to many other amino acid and complex protein supplements such as peptone and casamino acids. Yeast extract contains a mixture of growth factors and cofactors such as cAMP, vitamins and trace elements, which greatly enhanced growth of E. coli. In cAMP/PKA signaling pathway, cAMP binds to two sites on each regulatory subunit in cAMP-dependent protein kinase (PKA). Binding of four cAMP molecules releases two free and active catalytic subunits, which may phosphorylate serine and threonine residues on target pro- teins, resulting in the transcription $[17,18]$. Therefore, the transcriptional process could be enhanced in the presence of cAMP supplied by yeast extract, which subsequently increased the production of PrIFN- $\alpha 2 b$.

It is worth to note that PrIFN- $\alpha 2 b$ production was greatly reduced in fermentation using ammonium sulphate, though substantially high growth was observed. The inhibitory effect of ammonium was observed on the production of azadirachtin by Azadirachta indica [19]. Similarly, production of saponin and polysaccharide by Panax quinquefolium was also inhibited by the presence of ammonium [20].

Since higher growth of $E$. coli was obtained when yeast extract and peptone was used as the sole nitrogen source, the possibility of using them as a mixed nitrogen source was tested in Plackett-Burman design.

\section{Screening of Medium Constituents Using Plackett- Burman Experimental Design}

Table 4 shows the result of experiment using PlackettBurman design for PrIFN- $\alpha 2 b$ production by E. coli. Analysis of variance through factorial model (data not shown) suggested that glucose (A), yeast extract (C) and peptone (D) were the most significant factors that greatly influenced the

Table 3. Effect of Different Types of Nitrogen Sources on Growth of E. coli and Production of PrIFN-a2b.

\begin{tabular}{|c|c|c|c|c|c|}
\hline Nitrogen Source & $\begin{array}{c}\text { Final Cell } \\
\text { Concentration }(g / L)\end{array}$ & $\begin{array}{c}\text { Final PrIFN- } \alpha 2 b \\
\text { Concentration }(\mu \mathrm{g} / \mathrm{L})\end{array}$ & $\begin{array}{c}\text { Specific Yield } \\
\text { ( } \mu \mathrm{g} / \mathrm{g} \text { of Cell) }\end{array}$ & Time (h) & $\begin{array}{c}\text { Volumetric } \\
\text { Productivity }(\mu \mathrm{g} / \mathrm{L} / \mathrm{h})\end{array}$ \\
\hline Yeast extract & $0.64(0.025)$ & $20.8(3.664)$ & 32.5 & 8 & 2.6 \\
\hline Peptone & $0.48(0.056)$ & $3.8(0.827)$ & 7.9 & 8 & 0.5 \\
\hline Casamino acid & $0.39(0.047)$ & $0.8(0.236)$ & 2.1 & 8 & 0.1 \\
\hline
\end{tabular}

Each nitrogen source supplied the same amount of total $\mathrm{N}(10 \%)$. Glucose $(10 \mathrm{~g} / \mathrm{L})$ was used as a carbon source for all the experiments. The results of final cell concentration and final PrIFN- $\alpha 2 \mathrm{~b}$ are the average of duplicate experiments. The value in bracket is the standard deviation. Specific yield and volumetric productivity are calculated with the average values. Fermentation time is the time taken from inoculation to reach a maximum concentration of PrIFN- $\alpha 2 \mathrm{~b}$.

Table 4 Plackett-Burman Screening Design for Seven Variables and Predicted Responses for Improvement of PrIFN- $\alpha 2 b$ Production by $E$. coli

\begin{tabular}{|c|c|c|c|c|c|c|c|c|c|}
\hline Std & $\begin{array}{r}\text { A:glucose } \\
\text { (g/L) }\end{array}$ & $\begin{array}{r}\text { B:glycerol } \\
(\mathrm{g} / \mathrm{L})\end{array}$ & $\begin{array}{r}\begin{array}{l}\text { C:yeast } \\
\text { extract }\end{array} \\
(\mathrm{g} / \mathrm{L})\end{array}$ & $\begin{array}{r}\text { D:peptone } \\
(\mathrm{g} / \mathrm{L})\end{array}$ & $\begin{array}{r}\mathrm{E}: \mathrm{MgSO}_{4} \\
(\mathrm{~g} / \mathrm{L})\end{array}$ & $\begin{aligned} \mathrm{F}: \mathrm{NaCl} \\
\\
(\mathrm{g} / \mathrm{L})\end{aligned}$ & G:Initial pH* & $\begin{array}{r}\operatorname{PrIFN}-\alpha 2 b \\
(\mu \mathrm{g} / \mathrm{L})\end{array}$ & $\begin{array}{l}\text { DCW } \\
(\mathrm{g} / \mathrm{L})\end{array}$ \\
\hline 2 & 15 & 20 & 10 & 50 & 1 & 1 & 6 & 24.0 & 3.01 \\
\hline 3 & 5 & 20 & 50 & 10 & 10 & 1 & 6 & 87.0 & 3.30 \\
\hline 5 & 15 & 20 & 10 & 50 & 10 & 1 & 8 & 20.39 & 4.85 \\
\hline 6 & 15 & 20 & 50 & 10 & 10 & 10 & 6 & 16.9 & 2.90 \\
\hline 7 & 5 & 20 & 50 & 50 & 1 & 10 & 8 & 310.6 & 9.59 \\
\hline 8 & 5 & 5 & 50 & 50 & 10 & 1 & 8 & 295.0 & 8.19 \\
\hline 9 & 5 & 5 & 10 & 50 & 10 & 10 & 6 & 40.0 & 3.19 \\
\hline
\end{tabular}

*Initial $\mathrm{pH}$ refers to the $\mathrm{pH}$ of potassium buffer added to the sterile medium. 
production of PrIFN- $\alpha 2$ b by E. coli whereas glycerol, magnesium sulphate, $\mathrm{pH}$ and sodium chloride did not show significant effects on production of PrIFN- $\alpha 2 b$.

Results from experiment using Plackett-Burman design also shows that growth of $E$. coli and production of PrIFN$\alpha 2 b$ were repressed when concentration of glucose was high $(15 \mathrm{~g} / \mathrm{L})$. On the other hand, growth of $E$. coli and production of PrIFN- $\alpha 2 b$ was significantly enhanced at low glucose concentrations $(5 \mathrm{~g} / \mathrm{L})$. Highest PrIFN- $\alpha 2 \mathrm{~b}$ production was obtained from two runs among the twelve experiments, Run $7(310.6 \mu \mathrm{g} / \mathrm{L})$ and Run $8(295.0 \mu \mathrm{g} / \mathrm{L})$, where a combination of low glucose concentration $(5 \mathrm{~g} / \mathrm{L})$, high concentration (50 $\mathrm{g} / \mathrm{L}$ ) of yeast extract and peptone, while initial $\mathrm{pH}$ was set as 8 . Under non-optimal condition where glucose concentration was high $(15 \mathrm{~g} / \mathrm{L})$, change in $\mathrm{pH}$ did not largely affect the production of PrIFN- $\alpha 2 \mathrm{~b}$. In low glucose concentration (5 $\mathrm{g} / \mathrm{L}$ ), change in $\mathrm{pH}$ had a greater effect on PrIFN- $\alpha 2 \mathrm{~b}$ production. In short, result from this experiment indicates that the combination and interaction of various factors have different effects on growth of E. coli and PrIFN- $\alpha 2 \mathrm{~b}$ production.

\section{Optimization Using Response Surface Method}

Based on the preliminary study using Plackett-Burman, three variables (glucose, yeast extract and peptone concen- trations) were selected and their exact optimal values were determined using RSM. Central Composite Design (CCD) was used to study the interaction of significant variables and their optimal values. In CCD, glycerol was set at $10 \mathrm{~mL} / \mathrm{L}$ while the $\mathrm{pH}$ was adjusted with $0.1 \mathrm{M}$ potassium buffer of $\mathrm{pH}$ 7 , respectively. Glycerol was chosen to be constant due to the beneficial contribution in producing PrIFN- $\alpha 2 b$. From the previous Plackett-Burman experiment, it was found that E. coli consumed 4 to $5 \mathrm{~mL} / \mathrm{L}$ glycerol during the batch fermentation for PrIFN- $\alpha 2 b$ production.

Table 5 shows the experimental matrix for the three significant variables selected with the results of experimental and predicted response of PrIFN- $\alpha 2 \mathrm{~b}$ production by E. coli. The predicted PrIFN- $\alpha 2 b$ production achieved the maximum value of $318.1 \mu \mathrm{g} / \mathrm{L}$ when glucose, peptone and yeast extract concentrations were simultaneously increased to $6.5 \mathrm{~g} / \mathrm{L}$, $40 \mathrm{~g} / \mathrm{L}$ and $40 \mathrm{~g} / \mathrm{L}$, respectively. Reduced PrIFN- $\alpha 2 \mathrm{~b}$ production $(153.0 \mu \mathrm{g} / \mathrm{L})$ was obtained at the highest glucose concentration tested, indicating that the production was repressed at high glucose concentration. Inhibition of PrIFN$\alpha 2 \mathrm{~b}$ production was also observed at the highest concentration of yeast extract and peptone tested in this study (73.6 $\mathrm{g} / \mathrm{L})$. However, peptone gave greater inhibition compared to yeast extract.

Table 5. Full Factorial Central Composite Design (CCD) Matrix for the Three Significant Variables and Experimental and Predicted PrIFN-a2b Production by E. coli

\begin{tabular}{|c|c|c|c|c|c|}
\hline Std & $\begin{array}{c}\text { A:Glucose } \\
\text { (g/L) }\end{array}$ & $\begin{array}{c}\text { B:Yeast Extract } \\
(\mathrm{g} / \mathrm{L})\end{array}$ & $\begin{array}{c}\text { C:Peptone } \\
(\mathrm{g} / \mathrm{L})\end{array}$ & \multicolumn{2}{|c|}{$\operatorname{PrIFN}-\alpha 2 b(\mu \mathrm{g} / \mathrm{L})$} \\
\hline 1 & 3 & 20 & 20 & 78.3 & 66.4 \\
\hline 2 & 10 & 20 & 20 & 149.3 & 117.6 \\
\hline 3 & 3 & 60 & 20 & 228.4 & 163.6 \\
\hline 6 & 10 & 20 & 60 & 93.9 & 105.3 \\
\hline 7 & 3 & 60 & 60 & 334.2 & 312.4 \\
\hline 8 & 10 & 60 & 60 & 211.6 & 170.2 \\
\hline 12 & 6.5 & 73.636 & 40 & 220.8 & 275.9 \\
\hline 13 & 6.5 & 40 & 6.364 & 9.5 & 52.9 \\
\hline 14 & 6.5 & 40 & 73.636 & 135.6 & 167.7 \\
\hline 15 & 6.5 & 40 & 40 & 329.2 & 318.1 \\
\hline 16 & 6.5 & 40 & 40 & 314.0 & 318.1 \\
\hline 17 & 6.5 & 40 & 40 & 319.4 & 318.1 \\
\hline 18 & 6.5 & 40 & 40 & 319.1 & 318.1 \\
\hline 19 & 6.5 & 40 & 40 & 316.5 & 318.1 \\
\hline
\end{tabular}


A

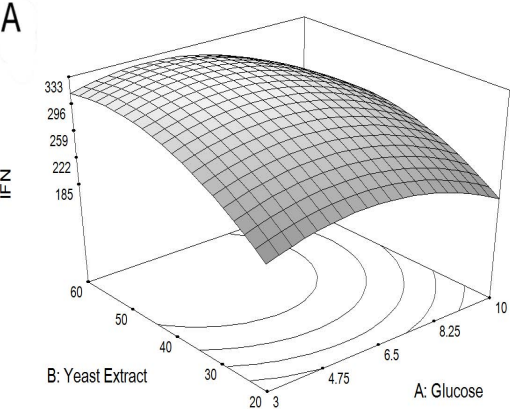

B

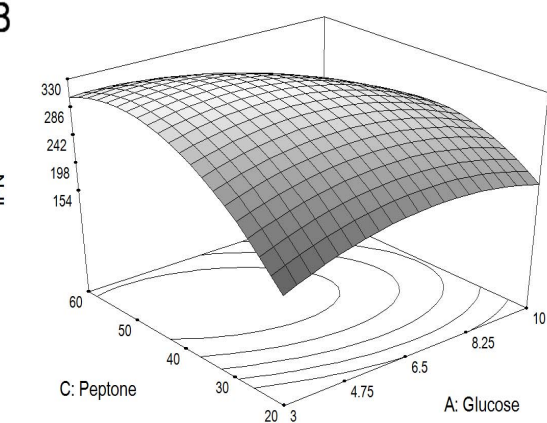

C

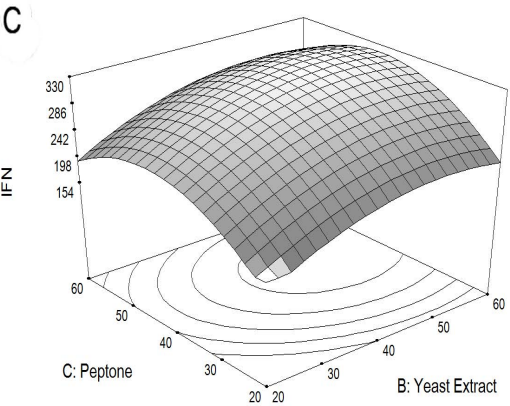

Fig. (1). Response surface 3D contour plots for effect of three main variables on PrIFN- $\alpha 2 b$ (PrIFN) production as (A) glucose and yeast extract concentrations; (B) glucose and peptone concentrations; and (C) yeast extract and peptone concentrations. When the effect of two variables was plotted, the other factor was set at middle level point. Y-axis is PrIFN- $\alpha 2 b$.

The response surface curve was plotted to determine the interaction and optimum values of the variables for PrIFN$\alpha 2 b$ (Fig. 1). The range of glucose concentration for maximum production of PrIFN- $\alpha 2 \mathrm{~b}$ was between $3 \mathrm{~g} / \mathrm{L}$ to $6 \mathrm{~g} / \mathrm{L}$ while the range of yeast extract and peptone for maximum production of PrIFN- $\alpha 2 \mathrm{~b}$ was between $45 \mathrm{~g} / \mathrm{L}$ to $55 \mathrm{~g} / \mathrm{L}$. The interaction between glucose and peptone is more significant compared to other two interactions as shown in the $F$ values (Table 6). The predicted model equation as shown below is observed to be reliable as the $F$-test analysis $=9.03$.

$\mathrm{Y}=\chi_{1}-\chi_{2} \mathrm{~A}+\chi_{3} \mathrm{~B}+\chi_{4} \mathrm{C}-\chi_{5} \mathrm{~A}^{2}-\chi_{6} \mathrm{~B}^{2}-\chi_{7} \mathrm{C}^{2}-\chi_{8} \mathrm{AB}-\chi_{9} \mathrm{AC}+\chi_{10} \mathrm{BC}$

where $\mathrm{Y}$ is PrIFN- $\alpha 2 \mathrm{~b}$ concentration; $\chi_{\mathrm{n}}$ is constant values; $\mathrm{A}$ is glucose concentration; $\mathrm{B}$ is yeast extract concentration and $\mathrm{C}$ is peptone concentration.

The significance of the model was validated with the predicted optimum values by the applied equation and experimental PrIFN- $\alpha 2 b$ production (Fig. 2). It was satisfactory since the plot was fitted to $y=x\left(R^{2}=0.8904\right)$. The final predicted optimal values of three variables were calculated based on equation and the values were found to be: $5.5 \mathrm{~g} / \mathrm{L}$ glucose, $55.2 \mathrm{~g} / \mathrm{L}$ yeast extract and $42.3 \mathrm{~g} / \mathrm{L}$ peptone. With these optimum variables, the predicted maximum production of PrIFN- $\alpha 2 b$ was $335.8 \mu \mathrm{g} / \mathrm{L}$. The optimized medium was then compared with commercial available media (M9, LB and TB). The experimental data for production of PrIFN- $\alpha 2 b$ in optimized media $(329.2 \mu \mathrm{g} / \mathrm{L})$ was $2.5,11.7$ and 124.4 times higher than TB $(134.7 \mu \mathrm{g} / \mathrm{L}), \mathrm{LB}(28.6 \mu \mathrm{g} / \mathrm{L})$ and M9 $(2.7 \mu \mathrm{g} / \mathrm{L})$, respectively.

Yeast extract was required to enhance growth and acetate utilization, while peptone improved growth and stabilized the enzymatic activity. Improved acetate utilization might be due to the presence of vitamins such as panthothenic acid, biotin and nicotinic acid which exists in large amount in yeast extract [21]. Stabilization of enzymatic activity by peptone was due to the supply of auxotrophic amino acids such as threonine and leucine in the culture [21, 22], which in turn, produced the desired protein at higher rate.

Table 6. Analysis of Variance (ANOVA) and Coefficient Estimate (CE) by Regression Model for the Optimization of PrIFN-a2b Production by $E$. coli in CCD

\begin{tabular}{|c|c|c|c|c|c|c|c|}
\hline Source & $\begin{array}{l}\text { Coefficient } \\
\text { Estimate }\end{array}$ & Standard Error & Sum of Squares & DF & Mean Square & F Value & Prob $>$ F \\
\hline Model & 318.14 & 18.31 & $1.637 \mathrm{E}+005$ & 9 & 18185.85 & 9.03 & 0.001 \\
\hline $\mathrm{A}$ & -22.76 & 12.15 & 7075.18 & 1 & 7075.18 & 3.51 & 0.090 \\
\hline B & 40.53 & 12.15 & 22437.73 & 1 & 22437.73 & 11.14 & 0.008 \\
\hline B2 & -39.03 & 11.82 & 21950.04 & 1 & 21950.04 & 10.89 & 0.008 \\
\hline $\mathrm{C} 2$ & -73.48 & 11.82 & 77814.14 & 1 & 77814.14 & 38.62 & $<0.0001$ \\
\hline $\mathrm{AB}$ & -8.40 & 15.87 & 564.10 & 1 & 564.10 & 0.28 & 0.608 \\
\hline Pure Error & & & 148.32 & 5 & 29.66 & & \\
\hline Cor Total & & & $1.838 \mathrm{E}+005$ & 19 & & & \\
\hline
\end{tabular}




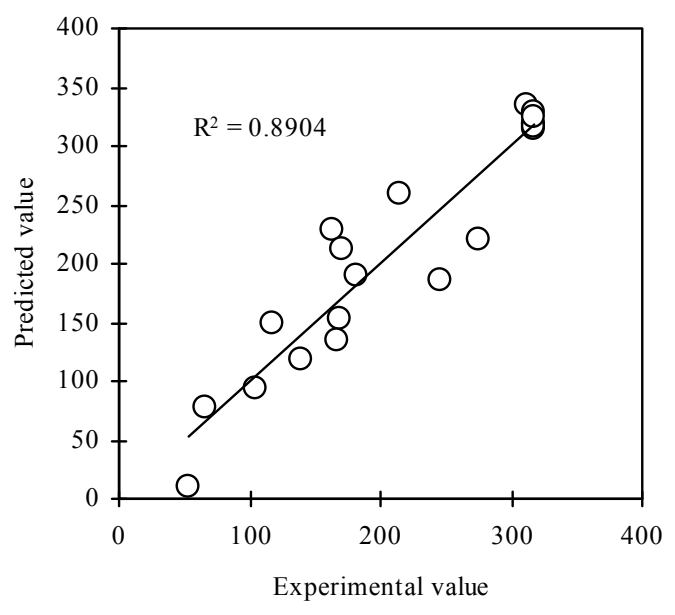

Fig. (2). Plot indicating the predicted values against experimental values for PrIFN- $\alpha 2 b$ (PrIFN) production. The linear line depicted represents $\mathrm{y}=\mathrm{x}$.

\section{Time Course of PrIFN-a2b Production by Recombinant E. coli}

The time course of PrIFN- $\alpha 2 \mathrm{~b}$ production by E. coli is shown in Fig. (3). The culture was induced after $4 \mathrm{~h}$ of cultivation at $37^{\circ} \mathrm{C}$. After the induction, the temperature was switched to $30^{\circ} \mathrm{C}$ to reduce the formation of inclusion bodies. Exponential growth phase was observed between 4 to $6 \mathrm{~h}$ of fermentation. Growth reached a stationary phase after $12 \mathrm{~h}$, followed by death phase after $18 \mathrm{~h}$. The PrIFN- $\alpha 2 \mathrm{~b}$ production was started after the induction $(4 \mathrm{~h})$, increased drastically and reached the highest concentration $(329.2 \mu \mathrm{g} / \mathrm{L})$ at 8 h. Substantial decrease in PrIFN- $\alpha 2 b$ with prolonged fermentation might be due to the degradation of the protein or leakage of protein into medium.

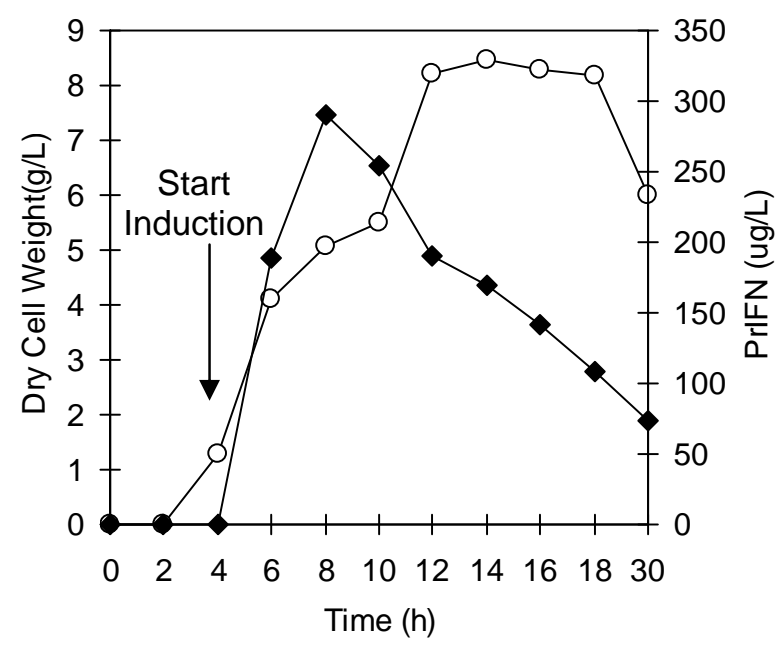

Fig. (3). Growth of E. coli and PrIFN- $\alpha 2 b$ (PrIFN) production in fermentation using optimized media.

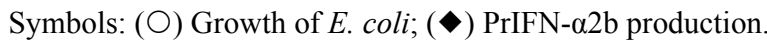

\section{CONCLUSION}

Statistical optimization using RSM was successfully used to optimize PrIFN- $\alpha 2 b$ production by E. coli. Plackett-
Burman design pre-selected the significant factors such as glucose, yeast extract and peptone. The medium formulation was further optimized using CCD where the most significant factors for enhancing production of PrIFN- $\alpha 2 b$ by E. coli were identified. The model equation was found adequate to predict the interactions among the variables and optimum concentration of the complex medium. The composition of optimized medium is $5.5 \mathrm{~g} / \mathrm{L}$ of glucose, $10 \mathrm{~mL} / \mathrm{L}$ of glycerol, $55.2 \mathrm{~g} / \mathrm{L}$ of yeast extract, $42.3 \mathrm{~g} / \mathrm{L}$ of peptone and 100 $\mathrm{mL} / \mathrm{L}$ of $0.1 \mathrm{M}$ potassium buffer at $\mathrm{pH} 7$. Production of PrIFN- $\alpha 2 b(329.2 \mu \mathrm{g} / \mathrm{L})$ using the optimized medium was 2.5, 11.7 and 124.4 times higher than those obtained in fermentation using TB, LB and M9, respectively.

\section{ACKNOWLEDGEMENTS}

This study was funded by the Ministry of Science, Technology and Innovation, Malaysia under the SRIRPA research grant (Project Number: 03-02-04 SR2010 SR0008/05). Tan Joo Shun, Siti Norani and Ramanan are recipients of graduate research fellowship from Universiti Putra Malaysia.

\section{REFERENCES}

[1] Terpe K. Overview of bacterial expression systems for heterologous protein production: from molecular and biochemical fundamentals to commercial systems. Appl Microbiol Biotechnol 2006; 72(2): 211-22.

[2] Choi JH, Lee SY. Secretory and extracellular production of recombinant proteins using Escherichia coli. Appl Microbiol Biotechnol 2004; 64(5): 625-35.

[3] Schmidt FR. Recombinant expression systems in the pharmaceutical industry. Appl Microbiol Biotechnol 2004; 65(4): 363-72.

[4] Baneyx F. Recombinant protein expression in Escherichia coli. Curr Opin Biotechnol 1999; 10(5): 411-21.

[5] Makrides SC. Strategies for achieving high-level expression of genes in Escherichia coli. Microbiol Mol Biol Rev 1996; 60(3): 512-38.

[6] Wang YS, Youngster S, Bausch J, Zhang R, McNemar C, Wyss DF. Identification of the major positional isomer of pegylated interferon alpha-2b. Biochemistry 2000; 39(35): 10634-40.

[7] Piper JM, Wen TTS, Xenakis EMJ. Interferon therapy in primary care. Prim Care Update Ob Gyns 2001; 8(4): 163-9.

[8] Stewart TA. Neutralizing interferon alpha as a therapeutic approach to autoimmune diseases. Cytokine Growth Factor Rev 2003; 14(2): 139-54.

[9] Valente CA, Prazeres DMF, Cabral JMS, Monteiro GA. Translational features of human alpha-2b interferon production in $E s$ cherichia coli. Appl Environ Microbiol 2004; 70(8): 5033-6.

[10] Srivastava P, Bhattacharaya P, Pandey G, Mukherjee KJ. Overexpression and purification of recombinant human interferon alpha $2 \mathrm{~b}$ in Escherichia coli. Protein Expr Purif 2005; 41(2): 313-22.

[11] Barbero J, Buesa J, Peñalva MA, Pérez-Aranda A, García J. Secretion of mature human interferon alpha 2 into the periplasmic space of Escherichia coli. J Biotechnol 1986; 4(5): 255-67.

[12] Ghosalkar A, Sahai V, Srivastava A. Secretory expression of interferon-alpha $2 \mathrm{~b}$ in recombinant Pichia pastoris using three different secretion signals. Protein Expr Purif 2008; 60(2): 103-9.

[13] Liu Y, Fu X, Shen J, Zhang H, Hong W, Chang Z. Periplasmic proteins of Escherichia coli are highly resistant to aggregation: reappraisal for roles of molecular chaperones in periplasm. Biochem Biophys Res Commun 2004; 316(3): 795-801.

[14] Srivastava P, Mukherjee KJ. Kinetic studies of recombinant human interferon-alpha (rhIFN-[alpha]) expression in transient state continuous cultures. Biochem Eng J 2005; 26(1): 50-8.

[15] Ramanan RN, Tey BT, Ling TC, Ariff AB. Classification of pressure range based on the characterization of Escherichia coli cell disruption in high pressure homogenizer. Am J Biochem Biotech 2009; 5(1): 21-9.

[16] Hansen R, Eriksen NT. Activity of recombinant GST in Escherichia coli grown on glucose and glycerol. Process Biochem 2007; 42(8): 1259-63. 
[17] Cooper DMF. Regulation and organization of adenylyl cyclases and cAMP. Biochem J 2003; 375(3): 517-29.

[18] Conti M, Richter W, Mehats C, Livera G, Park J-Y, Jin C. Cyclic AMP-specific PDE4 phosphodiesterases as critical components of cyclic AMP signaling. J Biol Chem 2003; 278(8): 5493-6.

[19] Prakash G, Srivastava AK. Statistical media optimization for cell growth and azadirachtin production in Azadirachta indica (A. Juss) suspension cultures. Process Biochem 2005; 40(12): 3795-800.

[20] Zhong J-J, Wang S-J. Effects of nitrogen source on the production of ginseng saponin and polysaccharide by cell cultures of Panax quinquefolium. Process Biochem 1998; 33(6): 671-5.
[21] Nancib N, Branlant C, Boudrant J. Metabolic roles of peptone and yeast extract for the culture of a recombinant strain of Escherichia coli. J Ind Microbiol Biotechnol 1991; 8(3): 165-9.

[22] Houtaia NE, Nancib N, Branlant G, Branlant C, Boudrant J. Production of glyceraldehyde-3-phosphate dehydrogenase using genetically engineered Escherichia coli. Biotechnol Lett 1989; 11(11): 775-8.

(c) Tan et al.; Licensee Bentham Open.

This is an open access article licensed under the terms of the Creative Commons Attribution Non-Commercial License (http://creativecommons.org/licenses/by-nc/3.0/) which permits unrestricted, non-commercial use, distribution and reproduction in any medium, provided the work is properly cited. 